Jurnal Riset Manajemen Sains Indonesia (JRMSI) | Vol 12, No. 2, 2021 e-ISSN: 2301-8313

http://doi.org/10.21009/JRMSI

DOI: doi.org/10.21009/JRMSI.009.1.08

\title{
PENGARUH PROSES REKRUTMEN SECARA ONLINE DAN OFFLINE TERHADAP KINERJA KARYAWAN PADA PERUSAHAAN STARTUP
}

\author{
Febriana Angelia Purba \\ Fakultas Teknik Universitas Singaperbangsa Karawang \\ Email: febriana.angelia17064@student.unsika.ac.id \\ Sukanta \\ Fakultas Teknik Universitas Singaperbangsa Karawang \\ Email: sukanta@staff.unsika.ac.id
}

\begin{abstract}
ABSTRAK
Penelitian ini dilakukan untuk mengetahui pengaruh penilaian kinerja karyawan melalui proses rekrutmen secara online dan offline berkaitan masa pandemic Covid-19. Berkaitan itu, maka kebutuhan karyawan tidaklah menginginkan hasil kerja keras dinilai secara subjektif, untuk itu maka tujuan dari penelitian ini adalah untuk mengetahui penilaian kinerja karyawan melalui proses rekrutmen secara online maupun offline. Dalam penelitian ini variabel dependen kinerja karyawan dan variabel independen proses rekrutmen. Teknik pengambilan sampel nya non-probability sampling, yaitu sampel jenuh pada bagian Information Technology dan Marketing \& Product Development. Metode analisis yang digunakan analisis kuantitatif diskritif dengan Human Resources Scorecard. Hasil dari penelitian ini menunjukkan bahwa pengaruh proses rekrutmen secara online terhadap kinerja karyawan pada bagian Information Technology sebesar 87,0\%, ini menunjukkan bahwa tidak berbeda secara signifikan. Sedangkan pengaruh proses rekrutmen terhadap kinerja karyawan pada bagian Marketing \& Product Development sebesar 90,5\%. Ini menunjukkan bahwa proses rekrutmen terhadap kinerja karyawan pada bagian Marketing \& Product Development berpengaruh secara signifikan.
\end{abstract}

Kata Kunci: Kinerja karyawan, Proses rekrutmen, Sumber daya manusia. 
Jurnal Riset Manajemen Sains Indonesia (JRMSI) | Vol 12, No. 2, 2021 e-ISSN: 2301-8313 http://doi.org/10.21009/JRMSI

\section{PENDAHULUAN}

Kondisi terakhir setelah menyebarnya virus Covid-19 membuat banyak perubahan disekitar lingkungan seluruh Negara di dunia. Hal ini juga mempengaruhi aktifitas perdagangan dan operasional pada perusahaan termasuk di Indonesia, dengan perekonomian Indonesia juga akan terpengaruh jika adanya gangguan terhadap perekonomian dunia. Banyak perusahaan kecil, menengah maupun besar yang akhirnya terpaksa menutup usahanya untuk sementara, dan tentu saja sektor industri yang paling terkena dampaknya terutama industri manufaktur. Namun untuk bisa keluar dari masalah kritis tersebut perusahaan harus cepat tanggap, agar bisa kembali menjalankan operasional dan beradaptasi dengan era baru yang sekarang di sebut New Normal. Kondisi seperti ini justru dapat dimanfaatkan bagi beberapa perusahaan rintisan seperti Startup dalam mengembangkan bisnis dan usaha di bidang teknologi digitalisasi era New Normal.

Dalam mempertahankan kualitas yang baik pada perusahaan dibutuhkan orang-orang yang mampu bertahan di situasi New Normal, dan selalu dapat memberikan ide-ide kreatif dalam mengembangkan suatu produk. Juga tidak jarang kemungkinan adanya pergantian karyawan atau turnover terlebih pada saat kondisi organisasi perusahaan yang tidak menentu karena pandemi saat ini. Untuk menjalankan roda produksi, sistem rekrutmen karyawan menjadi salah satu yang perlu diperhatikan pada saat situasi pandemi covid-19. Startup perusahaan menginginkan sumber daya terbaik didalamnya, dan dalam mengembangkan dan mencapai tujuan organisasi, faktor Human Resources atau Sumber Daya Manusia berperan sangat penting pada kualitas kinerja untuk mengetahui prestasi lembaga atau organisasi perusahaan tersebut. Menurut (Akbar, 2018) faktor-faktor yang memengaruhi kinerja individu tenaga kerja, yaitu:

a. Kemampuan individu tersebut,

b. Motivasi kerja,

c. Dukungan yang diterima,

d. Keberadaan pekerjaan yang mereka lakukan, dan

e. Hubungan mereka dengan organisasi.

Kualitas dan kuantitas dari suatu hasil kerja (output) individu maupun kelompok dalam suatu aktivitas tertentu yang diakibatkan oleh kemampuannya dari proses belajar, merupakan bentuk atau definisi dari kinerja. Pengukuran kualitas kinerja sendiri dilakukan untuk 
Jurnal Riset Manajemen Sains Indonesia (JRMSI) | Vol 12, No. 2, 2021 e-ISSN: 2301-8313 http://doi.org/10.21009/JRMSI

memberikan penilaian terhadap prestasi kerja yang diperoleh organisasi, tim, atau individu. Pengukuran kualitas kinerja sangat penting dilakukan karena akan memberikan umpan balik terhadap tujuan dan sasaran kualitas kinerja, perencanaan, dan proses pelaksanaan kualitas kinerja.

Hasil kajian melalui pengabdian yang dilakukan oleh (Sukanta et al., 2021) bahwa Sistem Manajemen K3 dan New normal dapat disimpulkan bahwa pemahaman dan kesadaran Sistem Manajemen K3, kemampuan untuk mengidentifikasi potensi bahaya, penilaian dan pengendalian resiko dilingkungan kerja, pemahaman untuk mematuhi dan menerapkan protol kesehatan new normal, kesadaran untuk menggunakan masker, kebiasaan cuci tangan dengan sabun dengan air mengalir dan bersih dan jaga jarak untuk setiap kegiatan apapun. Dengaan demikian, maka dengan kondisi penerapan siste manajemen K3 di atas dapat peningkatan terhadap kinerja karyawan dan sekaligus kinerja perusahaan.

Tujuan perusahaan akan tercapai jika terdapat orang-orang di dalamnya yang memiliki kualifikasi yang diharapkan oleh perusahaan. Maka dari itu, guna mendapatkan calon pegawai yang diinginkan sangat penting bagi perusahaan melakukan sistem recruitment yang tepat pada saat akan menempatkan seseorang atau sekelompok orang pada jabatan tertentu dalam perusahaan. Rekrutmen untuk mencari orang yang bercapability dalam melakukan pekerjaannya, sehingga dalam menentukan capability yang di miliki maka dilakukan penilaian kinerja, atau prestasi kerja.

Perusahaan startup yang baru meniti karir melakukan sistem recruitment pada karyawannya karena pasti menginginkan sekelompok tim yang terbaik untuk dipekerjakan. Adapun kunci sukses dari bisnis startup adalah adanya SDM yang cekatan, dan memiliki ide kreatif yang kemudian diolah dan menjadi sesuatu hal yang baru dan dipasarkan kepada masyarakat. Permasalahannya tidak semua manusia memiliki ide kreatif, maka diperlukan pemilihan untuk memastikan kecocokan antara jabatan yang kosong dan orang yang sesuai pada posisi tersebut, sehingga penempatan SDM memenuhi kriteria yang dibutuhkan demi kesejahteraan perusahaan.

Perusahaan startup sejak tanggal 15 Juli 2019 Masduit telah diakuisisi oleh perusahaan induk, dengan space waktu kurang lebih satu tahun dari tanggal berdirinya yaitu 18 Mei 2018. Pimpinan perusahaan (Bony Hudi, 2019) mengatakan akan semakin mudahnya proses untuk menabung hingga memiliki emas hanya dengan mengunduh aplikasi Masduit, dan selanjutnya transaksi emas dalam bentuk logam mulia dapat segera terjadi mulai dari jual- 
Jurnal Riset Manajemen Sains Indonesia (JRMSI) | Vol 12, No. 2, 2021 e-ISSN: 2301-8313 http://doi.org/10.21009/JRMSI

beli, mengambil dan transfer emas, hingga memonitoring harga dapat dilakukan melalui gadget tanpa harus datang langsung ke toko penjualan emas. Dengan kondisi yang semakin berkembang, perusahaan juga menginginkan staf handal, dan professional untuk mencapai tujuan perusahaan. Hal tersebut memerlukan perencanaan tenaga kerja yang baik untuk setiap divisi atau departemen dalam perusahaan. Namun mengingat kondisi dan keadaan pandemi saat ini, tentu saja rekrutmen yang dilakukan harus flexible dan mengikuti atau menyesuaikan keadaan yang ada. Peraturan pemerintah (Perpu) No 21 tahun 2020 tentang pembatasan sosial (Coppola \& Maloney, 2009) dalam rangka percepatan penanganan Corona Virus Disease 2019 (COVID-19), pembatasan yang dimaksud yaitu kegiatan tertentu dalam suatu wilayah berpenduduk yang diperkirakan terinfeksi COVID-19, untuk mencegah peluang penyebaran COVID-I9 tersebut. Sehingga untuk sistem perekrutan yang di tempuh dengan cara online merupakan pilihan yang tepat demi mematuhi perpu tersebut. Mengingat kebutuhan SDM yang diinginkan, tidaklah dimungkinkan perusahaan menghentikan perencanaan perekrutan, namun kondisi dan situasi di musim pandemic saat ini yang mengharuskan social distancing dapat menjadi kendala seperti technical test dilakukan di beberapa perusahaan secara langsung pada kandidat, kini technical test harus dikirimkan perusahaan secara online atau dengan jasa pengiriman agar tetap dapat diketahui apakah skill teknis yang dimiliki kandidat sesuai yang dicari. Saat ini perusahaan Startup lebih menitikberatkan pada proses interview daring, yang mana biasanya dilakukan secara langsung dengan tatap muka. Maka demikian, penelitian ini dilakukan dengan membandingkan kinerja karyawan dengan proses rekrutmen secara online maupun offline apakah berpengaruh terhadap kinerja karyawan dalam upaya mencari kesesuaian sistem perekrutan jarak jauh, sehingga jika dirasa kurang sesuainya pekerja yang direkrut dengan sistem rekrutmen yang telah berlangsung, dapat dilakukan improvement yang sesuai untuk perusahaan nantinya untuk sistem yang diberlakukan saat pandemi berlangsung.

\section{Rumusan Masalah}

Berdasarkan latar belakang diatas, terdapat berbagai permasalahan yang dapat dirumuskan sebagai berikut: 1). Apakah proses rekrutmen secara online pada bagian Information Technology berpenaruh terhadap kinerja kayawan pada perusahaan Startup? 2). Apakah proses rekrutmen secara online pada bagian Marketing\& Procuct Development terhadap kinerja karyawan pada perusahaan Startup? 3). Apakah ada perbedaan secara 
Jurnal Riset Manajemen Sains Indonesia (JRMSI) | Vol 12, No. 2, 2021 e-ISSN: 2301-8313 http://doi.org/10.21009/JRMSI

signifikan pada proses rekrutmen secara online pada bagian Information Technology dan bagian Marketing \& Product Development terhadap kinerja karyawan?

\section{Tujuan Penelitian}

Adapun tujuan pada penelitian ini sebagai berikut: 1). Untuk mengetahui apakah proses rekrutmen secara online pada bagian Information Tehcnology berpenaruh terhadap kinerja kayawan pada perusahaan Startup? 2). Untuk mengetahui apakah proses rekrutmen secara online pada Marketing \& Product Development terhadap kinerja karyawan pada perusahaan Startup? 3). Untuk mengetahui apakah ada perbedaan secara signifikan antara proses rekrutmen secara online pada bagian Information Tehcnology dan bagian Marketing \& Product Development terhadap kinerja karyawan perusahaan Startup?

\section{TELAAH PUSTAKA}

Pentingnya Manajemen sumber daya manusia (MSDM) pada saat melakukan sebuah planning pada perusahaan dikarenakan MSDM merupakan kumpulan pengetahuan tentang bagaimana seharusnya me-manage (mengelola) sumber daya manusia yang meliputi segi-segi perencanaan, pengorganisasian, pelaksanan, dan pengendalian fungsi produksi, pemasaran, maupun kepegawaian dalam pencapaian tujuan perusahaan (Dharmawan et al., 2018). Peran strategis manajemen sumberdaya manusia bisa dikatakan dapat meberikan added value sebagai tolak ukur keberhasilan suatu bisnis atau perusahaan. MSDM yang mana merupkan tempat pengelolaan Sumber Daya pada sebuah perusahaan tentu saja harus dilibatkan dalam setiap keputusan perusahaan, karena tanpa adanya manajemen yang bagus pasti akan sulit mengelola atau menjalankan suatu target yang ingin dicapai.

\section{Rekrutmen Jarak Jauh (online)}

Seiring dengan perkembangan zaman, dan pesatnya ilmu pengetahuan teknologi, sehingga tingkat kebutuhan organisasi pun beragam sesuai dengan permasalahan yang dihadapi era modern saat ini. Tentu saja peran organisasi harus flexible dalam mengatasi atau menjawab permasalahan yang ada di dalammnya. Semakin meningkatnya jumlah populasi manusia di dunia, maka akan semakin sulit juga dalam menjangkau dan menemukan calon pegawai yang sesuai dengan kriteria perusahaan. Namun, sejak pertengahan tahun 1990 proses rekrutmen mulai berkembang tidak lagi tradisional seperti membuat iklan di koran 
Jurnal Riset Manajemen Sains Indonesia (JRMSI) | Vol 12, No. 2, 2021 e-ISSN: 2301-8313 http://doi.org/10.21009/JRMSI

atau televisi, serta menggunakan agen karyawan. Proses rekrutmen online adalah proses perekrutan karyawan dengan menggunakan sumber daya elektronik, peran internet sangat membantu pada kegiatan ini. Bila di rata-ratakan mulai pada tahun 1998 sebesar 29\% perusahaan global telah menggunakan rekrutmen online, jumlah ini terus meningkat hingga tahun 1999 sebesar 60\%, tahun 2000 sebesar 79\%, dan pada tahun 2001 sudah 88\% proses rekrutmen jarak jauh (daring) telah dilaksanakan.

Selain dari pada itu, setiap proses rekrutmen yang dijalankan pasti memiliki hambatan didalamnya, berikut adalah hambatan yang ditemui dalam pelaksanaan seleksi:

a. Tingkat validitas yang berbeda karena metode-metode yang digunakan tersebut memiliki tingkat validitas yang berbeda-beda.

b. Hambatan biaya yang dimiliki perusahaan karena metode-metode itu memiliki biaya yang terkadang tidak murah. Untuk mengurangi kendala kendala ini, diperlukan kebijaksanaan seleksi secara bertingkat, karena semakin banyak tingkatan seleksi yang dilakukan semakin cermat dan teliti penerimaan karyawan.

c. Tolak ukur, yaitu kesulitan untuk menentukan standar yang akan digunakan mengukur kualifikasi-kualifikasi seleksi secara objektif. Misalnya; kejujuran, kesetiaan dan prakarsa dari pelamar mengalami kesulitan. Bobot nilai yang diberikan didasarkan pada pertimbangan yang subjektif.

d. Penyeleksi, yaitu kesulitan mendapatkan penyeleksi yang tepat, jujur dan objektif penilainnya. Penyeleksi sering memberikan nilai atas pertimbangan peranannya, bukan atas dasar pikirannya saja.

Pelamar, yaitu kesulitan untuk mendapatkan jawaban yang jujur dari pelamar. Mereka selalu berusaha memberikan jawaban mengenai hal-hal yang baik-baik saja tentang dirinya, sedangkan yang negative disembunyikan.

\section{Kinerja Karyawan}

Tenaga kerja atau man power secara makro adalah kelompok yang menduduki usia kerja. Maksudnya pengertian tenaga kerja bersifat kuantitas, yang mana mengarah kepada jumlah suatu penduduk yang masih dapat bekerja. Employee atau karyawan merupakan tenaga kerja dan dapat dikatakan juga seseorang yang mampu memberikan jasa dalam proses produksi hal ini dijabarkan secara mikro. Artinya tenaga kerja bersifat kualitas, yaitu sebagai 
Jurnal Riset Manajemen Sains Indonesia (JRMSI) | Vol 12, No. 2, 2021 e-ISSN: 2301-8313 http://doi.org/10.21009/JRMSI

jasa yang diberikan dalam proses produksi. Dalam konteks pengertian ini, maka tenaga kerja sering dipandang sebagai human atau intellectual capital perusahaan. Khususnya di Indonesia penerapan istilah tenaga kerja meliputi buruh, karyawan, dan pegawai (Siswanto, 2002).

Evaluasi atau penilaian bagi suatu pekerjaan sangat penting untuk dapat memperbaiki keputusan-keputusan personalia dan memberikan umpan balik kepada karyawan tentang pelaksanaan kerja mereka. Riset tentang MSDM mengarahkan bagaimana baiknya organisasi dapat mengimprove, menggunakan, mengevaluasi dan memelihara dalam kuantitas dan kualitas yang tepat. Kinerja karyawan tidak akan optimal apabila hanya mengandalkan mesin produksi tanpa memperhatikan aspek manusianya sebagai tempat pengelolaannya, menurut (Hani Handoko, 1999).

\section{Human Resources Scorcard}

Human Resources Scorecard merupakan turunan dari metode Balanced Scorecard dengan pendekatan Human Resources Departement. Balanced Scorecard menurut (Kaplan \& Norton, 2000) bahwa salah satu model sistem pengukuran kinerja yang diturunkan dari visi, misi dan berbagai tujuan strategis ke dalam beberapa perspektif yang berupa kartu skor-skor. Terdapat indikator kinerja kunci (KPI), yang mana rumusan dalam KPI merupakan salah satu proses dalam fungsi pengelolaan kinerja yakni menilai kinerja yang dilakukan karyawan secara obyektif. Dalam memonitor pencapaian target kerja sangatlah penting, karena pada hasilnya akan mengetahui langka pengambilan keputusan apa yang akan dilakukan oleh perusahaan dalam situasi kedepannya. Berikut merupakan pendekatan Balanced Scorecard dalam menentukan indikator KPI yang dapat memberikan penilaian kinerja karyawan:

1. Perspektif Financial, merupakan tolok ukur financial atau keuangan untuk memberi ringkasan dari konsekuensi.

2. Perspektif Customer, sebagai pengguna atau output dari implementasi strategi sumber daya manusia, merupakan tolak ukur karyawan sebagai asset.

3. Perspektif Internal Business Process yang mana akan memberikan dampak pada kepuasan customer, jadi memfokuskan pada manage proses internal. 
Jurnal Riset Manajemen Sains Indonesia (JRMSI) | Vol 12, No. 2, 2021 e-ISSN: 2301-8313 http://doi.org/10.21009/JRMSI

\section{MODEL PENELITIAN}

Uraian dari variabel proses rekrutmen secara online pada bagian Information Technology dan bagian Marketing \& Product Development terhadap kinerja karyawan dalam penelitian ini, dibuat kerangka model penelitian seperti gambar 1 berikut :

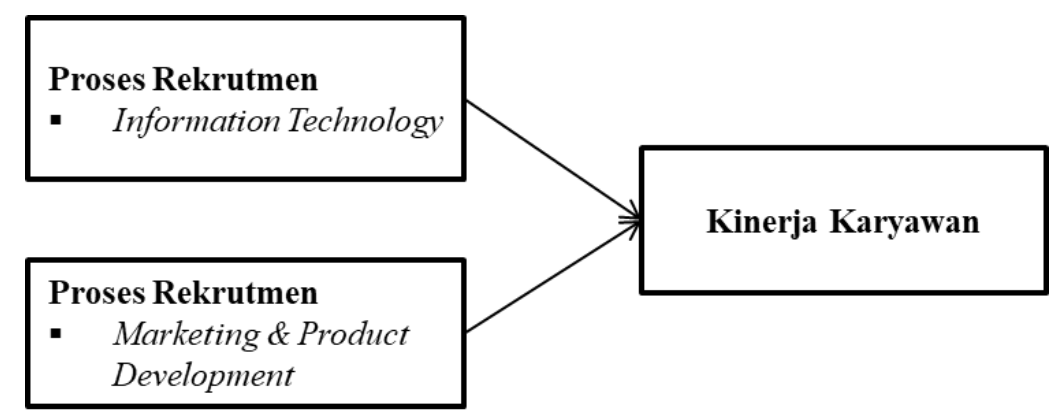

Gambar 1. Kerangka Penelitian

Sumber: Data diolah oleh peneliti (2020)

Adapun teknik pengumpulan data menggunakan metode wawancara dan observasi, dan kuisioner. Data dianalisis deskriptif dan dilakukan pengujian hipotesis yang dirumuskan untuk mengetahui adanya pengaruh variabel proses rekrutmen terhadap variabel kinerja karyawan dengan sampel data digeneralisir untuk populasi dengan kebutuhan data.

\section{HASIL DAN PEMBAHASAN}

Hasil penelitian terdapat perbedaan antara rekrutmen dan seleksi yang dilakukan merupakan terminologi yang lebih luas, dimana top management membuka lowongan dan sebaran informasi mengenai suatu posisi jabatan yang kosong didalam perusahaan. Sedangkan bagian kepegawaian perusahaan, perekrutan karyawan dan seleksi kerap dikombinasikan dengan "fungsi penempatan pegawai (employment function) dengan pertimbangan hasil rekomendasi melalui wawancara".

Tabel 1. KPI Pelaksana Information Technology (IT)

\begin{tabular}{|c|c|c|c|c|c|c|c|c|}
\hline \multirow[t]{2}{*}{ SK Jabatan IT } & \multirow[t]{2}{*}{ Bobot } & \multirow[t]{2}{*}{ Indikator Kinerja } & \multirow[t]{2}{*}{ Target } & \multicolumn{3}{|c|}{$\begin{array}{l}\text { Relasisasi aktua; } \\
\text { (Kuartal) }\end{array}$} & \multirow[t]{2}{*}{ Skor } & \multirow{2}{*}{$\begin{array}{c}\text { Nilai } \\
\text { Kinerja }\end{array}$} \\
\hline & & & & 1 & 2 & 3 & & \\
\hline $\begin{array}{l}\text { Membuat jadwal atau } \\
\text { planning informasi } \\
\text { secara berkala dan } \\
\text { akurat }\end{array}$ & $20 \%$ & $\begin{array}{l}\text { Prosentase } \\
\text { ketepatan waktu } \\
\text { pada pembuatan } \\
\text { jadwal }\end{array}$ & $95 \%$ & $83 \%$ & $79 \%$ & $88 \%$ & $79 \%$ & $15,83 \%$ \\
\hline $\begin{array}{l}\text { Meningkatkan } \\
\text { kreativitas dalam } \\
\text { mendesain akun } \\
\text { sosial media }\end{array}$ & $15 \%$ & $\begin{array}{l}\text { Skala ketertarikan } \\
\text { customer terhadap } \\
\text { desain akun } \\
\text { sosmed meningkat }\end{array}$ & 3 dari 4 & $2(60)$ & $3(80)$ & $3(80)$ & 73,33 & $11,00 \%$ \\
\hline http://journal.unj.ac.i & unj/ind & php/jrmsi & & & & & & 330 \\
\hline
\end{tabular}


Jurnal Riset Manajemen Sains Indonesia (JRMSI) | Vol 12, No. 2, 2021 e-ISSN: 2301-8313 http://doi.org/10.21009/JRMSI

\begin{tabular}{|c|c|c|c|c|c|c|c|c|}
\hline $\begin{array}{l}\text { Mengembangkan } \\
\text { Kompetensi diri } \\
\text { secara berkala }\end{array}$ & $5 \%$ & $\begin{array}{l}\text { Jumlah kegiatan } \\
\text { seminar yang } \\
\text { diikuti }\end{array}$ & $\begin{array}{l}12 \\
\text { kali/Tah } \\
\text { un }\end{array}$ & 1 & 1 & 1 & $100 \%$ & $5,00 \%$ \\
\hline \multirow{2}{*}{$\begin{array}{l}\text { Mempermudah } \\
\text { tampilan di sosial } \\
\text { media dengan efisein }\end{array}$} & $35 \%$ & $\begin{array}{l}\text { Tingkat } \\
\text { kemudahan } \\
\text { aktivitas akun } \\
\text { yang dapat di } \\
\text { akses dengan tepat } \\
\text { waktu }\end{array}$ & $100 \%$ & $74 \%$ & $83 \%$ & $89 \%$ & $82 \%$ & $31,83 \%$ \\
\hline & $10 \%$ & $\begin{array}{l}\text { Jumlah kesalahan } \\
\text { keamanan data di } \\
\text { akun, sosial media, } \\
\text { dan website }\end{array}$ & 0 & 0 & 0 & 0 & $100 \%$ & $10,00 \%$ \\
\hline $\begin{array}{l}\text { Mengelola pembuatan } \\
\text { katalog produk di } \\
\text { sosial media dengan } \\
\text { akurat }\end{array}$ & $25 \%$ & $\begin{array}{l}\text { Jumlah katalog } \\
\text { produk di sosial } \\
\text { media yang telah } \\
\text { dibagikan dengan } \\
\text { benar dan tepat } \\
\text { waktu }\end{array}$ & $100 \%$ & $85 \%$ & $95 \%$ & $100 \%$ & $93 \%$ & $23,33 \%$ \\
\hline Total & $100 \%$ & & & & & & & $87,00 \%$ \\
\hline
\end{tabular}

Di bagian Information Technology (IT) bahwa realisasi aktual, terdapat 24 jadwal informasi yang harus dibagikan kepada sosial media setiap bulannya, maka akan dihitung berapa jadwal informasi yang mampu diselesaikan tepat waktu yang harus dibagikan. Dan realisasi hanya 21 jadwal yang dapat diselesaikan dengan tepat waktu, sehingga target hanya $(21 / 24 \times 100 \%)=88 \%$. Hasil dari perhitungan bahwa proses rekrutmen secara online memiliki pengaruh terhadap kinerja karyawan pada bagian Information Technology sebesar $87.00 \%$, artinya bahwa proses rekrutmen secara online pada bagian Information Technology memiliki kinerja hampir sama atau tidak berbeda secara signifikan, lihat tabel $1 \mathrm{di}$ atas.

Sedangkan pada bagian Marketing \& Product Development terdapat sebanyak 35 data atau dokumen yang harus dikerjakan setiap bulannya. Setiap tugas bagian marketing diberi toleransi sebesar 5\% dikarenakan tanggung jawab pekerjaan. dan realisasi bagian Marketing \& Product Development sebesar $86 \%$. Didalam capaian bagian ini pada ukuran unit jumlah, atau angka kesalahan keamanan data targetnya senilai 0 . Karena perusahaan tidak menginginkan adanya kesalahan atau tidak menoleransi adanya kesalahan pada keamanan atau input data. Hasil penelitian menunjukkan bahwa proses rekrutmen pada bagian Marketing \& Product Development memberikan pengaruh terhadap kinerja karyawan sebesar 90.52\%, artinya bahwa proses rekrutmen pada bagia n Marketing \& Product Development secara online dapat meningkat secara signifikan, lihat tabel 2 di di bawah ini. 
Untuk ukuran unit skala pada target 3 dari 4, dikarenakan ada toleransi senilai 20 point pada target yang ditentukan untuk hasil survey, sehingga untuk ukuran unit skala terdapat point penilaian dirumuskan sebagai berikut:
a. Scale 4 its mean 100 point,
b. Scale 3 its mean 80 point,
c. Scale 2 its mean 60 point,
d. Scale 1 its mean 40 point, yang artinya point terkecil.

Tabel 2. KPI Pelaksana Marketing \& Product Development

\begin{tabular}{|c|c|c|c|c|c|c|c|c|}
\hline \multirow{2}{*}{$\begin{array}{l}\text { SK Jabatan } \\
\text { Marketing }\end{array}$} & \multirow{2}{*}{ Bobot } & \multirow{2}{*}{ Indikator Kinerja } & \multirow{2}{*}{ Target } & \multicolumn{3}{|c|}{$\begin{array}{l}\text { Relasisasi aktua; } \\
\text { (Kuartal) }\end{array}$} & \multirow{2}{*}{ Skor } & \multirow{2}{*}{$\begin{array}{c}\text { Nilai } \\
\text { Kinerja }\end{array}$} \\
\hline & & & & 1 & 2 & 3 & & \\
\hline $\begin{array}{l}\text { Menganalisis data } \\
\text { atau dokumen } \\
\text { kebutuhan customer } \\
\text { di pasaran }\end{array}$ & $15 \%$ & $\begin{array}{l}\text { Prosentase } \\
\text { ketepatan waktu } \\
\text { pada data atau } \\
\text { dokumen analisis }\end{array}$ & $95 \%$ & $86 \%$ & $\begin{array}{l}97 \\
\%\end{array}$ & $\begin{array}{l}89 \\
\%\end{array}$ & $86 \%$ & $12,89 \%$ \\
\hline $\begin{array}{l}\text { Memberikan sketsa } \\
\text { atau ide-ide desain } \\
\text { sebagai bahan } \\
\text { prototipe sebelum } \\
\text { dipasarkan }\end{array}$ & $35 \%$ & $\begin{array}{l}\text { Prosentase } \\
\text { ketepatan waktu } \\
\text { pada pembuatan } \\
\text { sketsa atau } \\
\text { prototipe produk }\end{array}$ & $95 \%$ & $91 \%$ & $\begin{array}{l}86 \\
\%\end{array}$ & $\begin{array}{l}94 \\
\%\end{array}$ & $86 \%$ & $30,08 \%$ \\
\hline $\begin{array}{l}\text { Mengelola inovasi } \\
\text { terkait produk agar } \\
\text { siap bersaing dengan } \\
\text { kompetitor dengan } \\
\text { pengembangan diri } \\
\text { mengikuti seminar }\end{array}$ & $5 \%$ & $\begin{array}{l}\text { Jumlah kegiatan } \\
\text { seminar marketing } \\
\text { and Product } \\
\text { Development yang } \\
\text { diikuti }\end{array}$ & $\begin{array}{l}12 \\
\text { kali/Tah } \\
\text { un }\end{array}$ & 1 & 1 & 1 & $100 \%$ & $5,00 \%$ \\
\hline \multirow{2}{*}{$\begin{array}{l}\text { Menjadi problem } \\
\text { solving terkait produk } \\
\text { yang dibutuhkan } \\
\text { customer, dan bahan } \\
\text { pengembangan }\end{array}$} & $20 \%$ & $\begin{array}{l}\text { Prosentase } \\
\text { permasalahan yang } \\
\text { dapat di selesaikan } \\
\text { dalam sistem } \\
\text { pengambilan } \\
\text { keputusan }\end{array}$ & $95 \%$ & $80 \%$ & $\begin{array}{l}94 \\
\%\end{array}$ & $\begin{array}{l}97 \\
\%\end{array}$ & $90 \%$ & $19,05 \%$ \\
\hline & $10 \%$ & $\begin{array}{l}\text { Jumlah kesalahan } \\
\text { pengembangan } \\
\text { operasional yang } \\
\text { dijalankan }\end{array}$ & 0 & 0 & 0 & 0 & $100 \%$ & $10,00 \%$ \\
\hline $\begin{array}{l}\text { Mengelola pembuatan } \\
\text { desain produk tematik } \\
\text { sesuai dengan hari } \\
\text { besar secara berkala }\end{array}$ & $15 \%$ & $\begin{array}{l}\text { Prosentase jumlah } \\
\text { pembuatan desain } \\
\text { produk tematik } \\
\text { sesuai dengan hari } \\
\text { besar dengan tepat } \\
\text { waktu }\end{array}$ & $100 \%$ & $85 \%$ & $\begin{array}{l}90 \\
\%\end{array}$ & $\begin{array}{l}95 \\
\%\end{array}$ & $90 \%$ & $13,50 \%$ \\
\hline Total & $100 \%$ & & & & & & & $90,52 \%$ \\
\hline
\end{tabular}


Jurnal Riset Manajemen Sains Indonesia (JRMSI) | Vol 12, No. 2, 2021 e-ISSN: 2301-8313 http://doi.org/10.21009/JRMSI

\section{KESIMPULAN DAN SARAN}

\section{Kesimpulan}

Berdasarkan hasil penelitian dan pembahasan, maka dapat disimpulkan bahwa : 1). Terdapat pengaruh variabel proses rekrutmen melalui secara online terhadap kinerja karyawan pada bagian Information Technology dengan nilai KPI sebesar $87.00 \%$. Ini menunjukkan bahwa proses rekrutmen secara online terhadap kinerja karyawan tidak berbeda secara signifikan. 2). Terdapat pengaruh variabel proses rekrutmen melalui secara online terhadap kinerja karyawan pada bagian Marketing \& Product Development dengan nilai KPI sebesar $90.52 \%$. Ini menunjukkan bahwa proses rekrutmen secara online terhadap kinerja karyawan lebih baik dan berbeda secara signifikan. 3). Adanya perbedaan pengaruh proses rekrutmen dengan melalui secara online pada bagian Information Technology dan bagian Marketing \& Product Development sebesar $(90.52 \%-87.00 \%=3.52 \%$. Ini menunjukkan bahwa proses rekrutmen secara online terhadap kinerja karyawan pada bagian Marketing \& Product Development lebih tinggi sebesar $3.52 \%$.

\section{Saran}

Berdasarkan hasil penelitian dan pembahasan, bahwa saran-saran yang peneliti sebagai berikut : 1). Proses rekrutmen secara online terhadap peningkatan kinerja karyawan dapat dilakukan dalam proses rekutmen terutama dalam kondisi pandemic covid-19 dan perlu dilakukan pada bagian yang berbeda pada perusahaan yang bersangkutan. 2). Penelitian selanjutnya, peneliti dapat menyarankan bahwa perlu dilakukan tambahan variabel sistem pendukung keputusan pada top management dan penelitan pada bagian yang lain dalam penempatan posisi atau jabatan sesuai dari hasil prestasi kerja. 
Jurnal Riset Manajemen Sains Indonesia (JRMSI) | Vol 12, No. 2, 2021 e-ISSN: 2301-8313 http://doi.org/10.21009/JRMSI

\section{DAFTAR PUSTAKA}

Akbar, S. (2018). Faktor yang mempengaruhi kinerja anggota organisasi. Jiaganis, 3(2), 117.

Coppola, D. P., \& Maloney, E. K. (2009). Communicating Emergency Preparedness. Communicating Emergency Preparedness, 2019(022868). https://doi.org/10.4324/9780367802820

Dharmawan, R., Susilo, H., \& Aini, E. K. (2018). Analisis Efisiensi Rekrutmen Karyawan Melalui Media Online dan Media Konvensional (Studi Tentang Efisiensi Waktu dan Tenaga dari PT. Jasa Marga (persero) Tbk). Jurnal Administrasi Bisnis (JAB), 64(1), $161-170$.

Handoko, Hani, (1999), Dasar-dasar manajemen Porduksi dan Operasi, Terbitan Bpfe, Yogyakarta.

Putri, dkk, (2021), Penerapan Media Podcast terhadap Menyimak Puisi dalam Pembelajaran Daring Siswa, Jurnal EDUKATIF Jurnal Ilmu Pendidikan, Vol 3 No. 5

Siswanto, B. Sastrohadiwirya, (2003), Manajemen tenaga kerja Indonesia : pendekatan administrasi dan operasional, Terbitan Bumi Aksara, Jakarta.

Sukanta, Musadad, A., \& Sari, D. A. (2021). Pelatihan sistem manajemen K3 dan new normal industri di PT TEiN. Prosiding Seminar Nasional REKARTA 